\title{
PENGARUH PENERAPAN DISIPLIN KERJA DAN KOMITMEN KERJA TERHADAP KINERJA KARYAWAN PADA PABRIK PENGOLAHAN KEDELAI DI DESA LAREN LAMONGAN
}

\author{
Mohamad Rizal Nur Irawan \\ Prodi Manajemen, Fakultas Ekonomi, Universitas Islam Lamongan \\ $\mathrm{Jl}$. Veteran No.53A Lamongan \\ Telp. ( 0322 ) 324706, Faks. ( 0322 ) 324706 \\ rizalirawan@unisla.ac.id/rijalunisla@gmail.com
}

\begin{abstract}
Abstrak
Kinerja karayawan masih menjadi faktor utama dalam suatu perusahaan sehingga ada beberapa starategi dalam meningkatkan kinerja karyawan yaitu kedisiplinan dan komitmen kerja. Penelitian ini bertujuan untuk mengetahui apakah variabel bebas memiliki pengaruh secara parsial maupun secara simultan terhadap variabel terikat. Metode dalam penelitian ini yaitu jenis penelitian eksplanatori dengan pendekatan kuantitatif dengan menggunakan uji validitas, reliabilitas, uji asumsi klasik, analisis regresi linier berganda, korelasi berganda, koefisien determinasi, uji $\mathrm{t}$ dan uji $\mathrm{F}$ dengan menggunakan olah data SPSS (statistical package for social) versi 20.0. Hasil penelitian ini dapat disimpulkan bahwa disiplin kerja memiliki pengaruh secara parsial sedangkan komitmen kerja tidak berpengaruh, serta yang berpengaruh paling dominan terhadap kinerja karyawan adalah disiplin kerja karena nilai komitmen kerja lebih kecil daripada nilai disiplin kerja. Dengan demikian adanya penelitian ini, diharapkan dapat memberikan kontribusi atau dapat dijadikan sebagai bahan pertimbangan dalam menjalankan industrinya untuk meningkatkan kinerja karyawan.
\end{abstract}

Kata Kunci :Disiplin kerja, komitmen kerja dan kinerja karyawan.

\section{PENDAHULUAN}

Dengan perkembangan zaman yang semakin modern, tentu membuat kebutuhan semakin meningkat. Hal ini juga berdampak pada usaha kecil ataupun usaha besar yang sekarang mulai berkembang dan muncul usaha-usaha baru yang inovatif dan beragam. Maka dari itu suatu perusahaan perlu adannya pembangunan ketenagakerjaan yang tidak hanya dengan kepentingan tenaga kerja semata, untuk itu diperlukan pengaturan yang menyeluruh dan komperhensif, yaitu yang mencakup sumber daya manusia.

Sumber daya manusia memegang peranan yang sangat penting dalam pengembangannya 
terutama bila diinginkan pencapaian tujuan yang optimal, sebab dengan tidak adanya tenaga kerja atau karyawan yang profesional atau komperhensif perusahaan tidak dapat melakukan aktifitasnya secara maksimal. Melihat sangat pentingnya peranan tenaga kerja sebagai sumber daya manusia dalam proses produksi sehingga diharapkan karyawan akan dapat bekerja lebih produktif dan profesional dengan didorong oleh rasa aman dalam melakukan aktivitasnya.

Persaingan bisnis yang ketat mengharuskan perusahaan mempunyai manajemen yang baik. Manajemen yang baik merupakan proses dimana pelaksanaan suatu tujuan tertentu diselenggarakan dan diawasi. Manajemen yang juga sebagai proses yang berkenaan dengan usaha manusia untuk melalui bantuan manusia lain melaluai cara yang efektif dan efesien untuk mencapai tujuan yang ditentukan. Proses manajemen akan lebih optimal jika fungsi-fungsi dalam manajemen berjalan dengan baik. Dasar-dasar manajemen mencakup perencanaan (planning), pengorganisasian (organizing), pelaksanaan (actuating), dan pengawasan (controlling). Keempat fungsi inilah yang menjadi inti dalam proses pengawasan.

Salah satu faktor yang sangat mempengaruhi dalam sumber daya manusia adalah kedisiplinan. Kedisiplinan merupakan kondisi atau sikap dan perilaku yang ada pada diri karyawan terhadap peraturan yang berlaku. Pada pabrik pengolahan kedelai tingkat kedisiplinan sangat rendah ini terlihat dari beberapa karyawan yang datang terlambat, namun tidak diberikan sanksi yang tegas. Hal ini memberikan pengaruh yang cukup berarti terhadap tingkat kinerja karyawan yang menyebabkan karyawan tidak dapat menyelesaikan pekerjaan dengan maksimal dan sesuai target yang telah ditetapkan, sehingga sulit untuk pencapaian tujuan yang ditetapkan sebelumnya.

Salah satu keberhasilan satu manajemen perusahaan adalah kemampuannya dalam menumbuhkan organisasional karyawan. Komitmen organisasional karyawan sangatlah penting karena karyawan yang memiliki komitmen yang kuat terhadap perusahaan akan menampilkan kinerja terbaiknya 
serta produktif dalam mengemban pekerjaan. Pada perusahaan pabrik pengolahan kedelai tingkat komitmen karyawan dengan perusahaan yang masih rendah terlihat dari karyawan yang masih mendahulukan kepentingan pribadi dan tidak melaksanakan kesepakatan yang telah dibuat sehingga berpengaruh bagi produktifitas perusahaan.

Kinerja bukan merupakan karakteristik individu, seperti bakat / kemampuan, melainkan perwujudan dan bakat atau kemampuan itu sendiri. Kinerja merupakan perwujudan dari kemampuan dalam bentuk karya nyata atau merupakan hasil kerja yang dicapai karyawan dalam mngemban tugas dan pekerjaan yang berasal dari perusahaan. Tertapi terdapat permasalahan karyawan pada pabrik pengolahan kedelai yaitu sering datang terlambat, melanggar prosedur, komunikasi yang masih rendah, kurang inisiatif sehingga kinerja karyawan diperusahaan masih kurang maksimal.

Penerapan disiplin, dan komitmen kerja pada pabrik pengolahan kedelai berharap dapat menambah kualitas kerja yang mampu mengelola perusahaan dengan baik dan professional, sehingga untuk kedepannya peusahaan tersebut dapat mencapai keberhasilan yang baik untuk memajukan suatu perusahaan pengolahan kedelai. Bidang ini dipilih biasanya yang tidak memerlukan modal besar serta teknologi yang tidak rumit. Salah satu bidang usaha yang dipilih adalah usaha tahu tempe.

Bahan baku utama dalam pembuatan tahu dan tempe adalah kedelai. Kedelai sendiri mengandung zat gizi tetapi secara alami mengandung zat anti gizi antara lain Tripsin Inhibitor, Asam Fitat, Saponin, serta anti gizi yang lain. Tripsin Inhibitor adalah senyawa yang menghambat aktivitas tripsin, padahal Tripsin adalah Enzim pencerna protein yang dihasilkan oleh pangkreas. Jika tripsin terbloker oleh tripsin inhibitor maka aktivitas tripsin dalam mencerna protein akan terhambat, artinya protein yang didapat dalam makanan menjadi tidak dapat dicerna oleh tubuh atau tarbuang sia-sia. 
Sedangkan asam fitat akan mengikat mineral seng, besi dan kalsium dalam makanan dan berdampak pada ketidak ketersediaan mineral tersebut pada makanan. Saponi banyak terdapat pada kulit kedelai yang menyebabkan rasa pahit. Sebenarnya senyawa-senyawa anti gizi tersebut diatas dapat dinetralisir atau inaktivasi dengan pemanasan yang sempurna. Maka dari itu agar produksi tahu tempe ini bagus dan dapat berjalan dengan baik maka perusahaan harus memberikan arahan kepada seluruh karyawan untuk menjalakan tugasnya dengan baik dan menaati peraturan yang telah ditetapkannya.

Berdasarkan uraian diatas, maka penulis berkeinginan untuk melakukan penelitian lebih dalam tentang penerapan disiplin kerja dan komitmen kerja karyawan yang diberikan untuk perusahaannya. Maka penulis tertarik untuk mengambil judul penelitian :“ Pengaruh Penerapan Disiplin Kerja Dan Komitmen Kerja Terhadap Kinerja Karyawan Pada Pabrik Pengolahan Kedelai Di Desa Laren Lamongan".
Berdasarkan latar belakang tersebut diatas maka dapat dirumuskan masalah sebagai berikut antara lain :

1. Apakah penerapan disiplin dan komitmen kerja berpengaruh secara parsial terhadap kinerja karyawan?

2. Apakah penerapan disiplin dan komitmen kerja berpengaruh secara simultan terhadap kinerja karyawan?

3. Variabel manakah diantara penerapan disiplin dan komitmen kerja yang paling berpengaruh secara dominan terhadap kinerja karyawan?

Adapun tujuan dari penelitian ini adalah untuk mengetahui pengaruh secara parsial dan simultan disiplin kerja dan komitmen kerja terhadap kinerja karyawan pada pabrik pengolahan kedelai. Dan untuk mengetahui variabel yang paling dominan mempengaruhi kinerja karyawan pada pabrik pengolahan kedelai.

\section{KAJIAN PUSTAKA}

Manajemen Sumber Daya

\section{Manusia}


Menurut Hasibuan (2014:10) MSDM adalah ilmu dan seni mengatur hubungan dan peranan tenaga kerja agar efektif dan efisien membantu terwujudnya tujuan perusahaan, karyawan, dan masyarakat.

\section{Disiplin kerja}

Menurut Hasibuan (2015), kedisiplinan adalah kunci keberhasilan suatu perusahaan dalam mencapai tujuannya.

\section{Komitmen kerja}

Allen dan Meyer dalam Darmawan (2013:169) bahwa: "komitmen organisasi adalah sebuah konsep yang memiliki tiga dimensi, yaitu komitmen efektif, berkelanjutan dan normatif'. Komitmen sering dikaitkan dengan keadaan dimana seorang pegawai memihak organisasi tertentu serta tujuan-tujuan dan keinginannya untuk mempertahankan keanggotaan dalam organisasi.

\section{Kinerja karyawan}

Menurut (A.A. Prabu Mangkunegara, 2010:9) kinerja adalah prestasi kerja atau hasil kerja (output) baik kualitas maupun kuantitas yang dicapai sumber daya manusia.

\section{METODE PENELITIAN}

Penelitian ini mengunakan jenis penelitian kuantitatif. Menurut
Sugiyono (2012), menyatakan bahwa penelitian kuantitatif dapat diartikan sebagai metode penelitian yang berlandaskan pada filsafat positivisme, digunakan untuk meneliti pada populasi atau sampel tertentu.

Dengan menggunakan metode analisa data uji validitas, uji reliabilitas, uji asumsi klasik dan uji hipotesis dengan analisis regresi linier berganda, korelasi berganda, koefisien determinasi, uji t, dan Uji F.

Dengan populasi karyawan yang berjumlah 35 sampel yaitu teknik sampling adalah simple random sampling yang artinya mengambil data secara acak tanpa memandang strata yang ada dalam populasi tersebut.

Adapun jenis data yang digunakan adalah :

1) Data Primer

Merupakan data yang diperoleh dari obyek yang akan diteliti secara langsung. Dalam penelitian ini, data primer di dapat langsung dari responden dengan cara menyebarkan kuesioner dan wawancara langsung kepada karyawan pabrik pengolahan kedelai. 
2) Data Sekunder

Data sekunder merupakan data yang diperoleh dari studi kepustakaan antara lain mencakup dokumen-dokumen resmi, buku-buku, hasil-hasil penelitian yang berwujud laporan dan sebagainya.

Dalam penelitian ini menggunakan pernyataan yang nantinya akan dianalisa secara kuantitatif dengan menggunakan Skala Likert. Skala Likert adalah skala yang digunakan untuk mengukur sikap, pendapat, dan persepsi seseorang atau sekelompok orang tentang fenomena sosial (Sugiyono, 2015).

\section{HASIL DAN PEMBAHASAN}

Berdasarkan hasil analisisa data yang dilakukan maka dapat disimpulkan sebagai berikut :

1. Uji validitas ini dilakukan untuk mengetahui kevalidan angket dalam mengumpulkan data. Item angket dikatakan valid jika $\mathrm{r}_{\text {hitung }}$ $>r_{\text {tabel }}$ pada nilai signifikan $5 \%$, sebaliknya dikatakan tidak valid jika $\mathrm{r}_{\text {hitung }}<\mathrm{r}_{\text {tabel }}$ pada nilai signifikan 5\%. dapat diketahui bahwa untuk masing - masing soal pada setiap indikator variabel bebas dari disiplin kerja $\left(\mathrm{X}_{1}\right)$, komitmen kerja $\left(\mathrm{X}_{2}\right)$ dan kinerja karyawan (Y) memiliki nilai sig ( 2 tailed $)<\mathrm{p}=0.05$ dan nilai $r$ hitung $>r_{\text {tabel}}$, maka dapat disimpulkan bahwa instrumen yang digunakan dalam penelitian ini adalah valid.

2. Dari uji reliabilitas, ini dilakukan untuk menunjukkan konsistensi suatu angket dapat dipercaya atau dapat digunakan. dapat diketahui nilai alpha variabel bebas yaitu disiplin kerja $\left(\mathrm{X}_{1}\right)$, komitmen kerja $\left(\mathrm{X}_{2}\right)$ dan variabel terikat kinerja karyawan (Y) lebih besar dari nilai kritis (0.6), dengan tingkat signifikan

$\mathrm{a}=5 \%$ sehingga dapat disimpulkan bahwa instrument yang digunakan dalam penelitian ini yaitu reliabel.

Tabel 1. Hasil Uji Reliabilitas

\begin{tabular}{|l|l|l|}
\hline Variabel & $\begin{array}{c}\text { Cronbach's } \\
\text { alpha if } \\
\text { item } \\
\text { deleted }\end{array}$ & $\begin{array}{c}\text { Standar } \\
\text { reliabilitas }\end{array}$ \\
\hline $\begin{array}{l}\text { Disiplin kerja } \\
\left(\mathrm{X}_{1}\right)\end{array}$ & 0,627 & 0,6 \\
\hline $\begin{array}{l}\text { Komitmen } \\
\text { kerja }\left(\mathrm{X}_{2}\right)\end{array}$ & 0,718 & 0,6 \\
\hline Kinerja & 0,816 & 0,6 \\
\hline
\end{tabular}




\begin{tabular}{|c|c|c|}
\hline Variabel & $\begin{array}{c}\text { Cronbach's } \\
\text { alpha if } \\
\text { item } \\
\text { deleted }\end{array}$ & $\begin{array}{c}\text { Standar } \\
\text { reliabilitas }\end{array}$ \\
\hline karyawan (Y) & & \\
\hline
\end{tabular}

3. Dari uji asumsi klasik,

Uji Normalitas digunakan untuk menguji data variabel bebas dan data variabel terikat pada persamaan regresi yang dihasilkan berdistribusi normal atau berdistribusi tidak normaldengan kriteria pengujian sebagai berikut :

a. Asymp. Sig > 0,05, maka data berdistribusi normal

b. Asymp. Sig < 0,05, maka data berdistribusi tidak normal Pada penilitian ini menunjukkan nilai kolmogrov smirnov sebesar 0.648 dengan nilai probabilitas signifikan (Asymp. Sig) sebesar 0.794. karena nilai $\mathrm{p}$ atau Asymp. Sig > 0.05, maka dapat dijelaskan bahwa data residual terdistribusi normal. Dan dilihat dari gambar p-p plot diketahui bahwa data menyebar disekitar garis diagonal dan mengikuti garis diagonal maka dapat dikatakan bahwa model regresi dalam penelitian ini dapat dikatakan normal.
Uji Multikolinieritas Digunakan untuk mengetahui kesalahan standard estimasi dalam model penelitian. Ada 2 cara untuk mengetahui tidak atau terjadinya multikolinieritas dalam penelitian yaitu :

a. Tidak terjadi multikolinieritas jika nilai tolerance $>0.10$

b. Tidak terjadi multikolinieritas jika nilai $\mathrm{VIF}<10.00$.

Pada penelitian ini diperoleh nilai VIF dari semua variabel independen dalam penelitian ini mempunyai nilai VIF < 10, dan nilai tolerance > 0,1 maka dapat dijelaskan bahwa data terbebas dari multikolinieritas.

\section{Uji Heterokedastisitas Untuk} menguji apakah dalam model regresi terjadi ketidaksamaan variance dari residual satu pengamatan ke pengamata lain. Jika variance residual satu pengamatan ke pengamatan lain tetap, maka disebut homokedastisitas. Ada beberapa cara untuk mendeteksi ada atau tidaknya heteroskesdastisitas, antara lain:

Melihat grafik plot antara nilai prediksi variabel terikat (dependen) yaitu ZPRED dengan residual SRESID. Deteksi ada 
tidaknya heteroskedastisitas dapat dilakukan dengan melihat ada tidaknya pola tertentu pada grafik scatterplot antara SRESID dan ZPRED dimana sumbu $\mathrm{Y}$ adalah $\mathrm{Y}$ yang telah diprediksi dan sumber $\mathrm{X}$ adalah residual ( $\mathrm{Y}$ prediksi $-\mathrm{Y}$ sesungguhnya) yang telah distudentized.

Diperoleh hasil dari scatter plot yang terlihat bahwa titik - titik yang terbentuk tidak memiliki pola yang jelas, serta plot menyebar di atas dan di bawah angka 0 pada sumbu Y, maka dapat dijelaskan bahwa data tidak terjadi heterokedastisitas.

Uji Autokorelasi bertujuan untuk menguji apakah dalam model regresi linier berganda ada korelasi antara kesalahan penganggu pada periode $t$ dengan kesalahan pengganggu. Pada periode $\mathrm{t}-1$ (sebelumnya). diperoleh nilai Durbin Watson sebesar 2.432 yaitu nilai DW berada di atas 1.55 dan lebih kecil dari 2.46 maka dapat disimpulkan bahwa tidak terdapat autokorelasi pada penelitian ini.

4. Dari uji analisis regresi linier berganda dilakukan untuk menganalisa pengaruh variabel bebas yaitu disiplin kerja $\left(\mathrm{X}_{1}\right)$, komitmen kerja $\left(\mathrm{X}_{2}\right)$, terhadap variabel terikat kinerja karyawan (Y) dapat diketahui hasilnya:

$$
\mathrm{Y}=0,509+0,652 \mathrm{X}_{1}+0,323 \mathrm{X}_{2} \text {. }
$$

Hal ini dapat memberikan implikasi bahwa disiplin kerja $\left(\mathrm{X}_{1}\right)$ dan komitmen kerja mempengaruhi kinerja karyawan.

a) $\alpha=0,509$ adalah konstanta yang menunjukkan dari nilai $\mathrm{Y}$ (kinerja karyawan) pada saat nilai $X$ sama dengan 0 .

b) $\mathrm{b} 1=0.652$ menunjukkan koefisien regresi untuk $\mathrm{X}_{1}$. Hal ini berarti jika variabel $\mathrm{X}_{1}$ naik satu satuan maka mempengaruhi disiplin kerja dalam meningkatkan kinerja karyawan sebesar 0.652 .

c) b2 $=0,323$ menunjukkan koefisien regresi untuk $\mathrm{X}_{2}$. Hal ini berarti jika variabel $X_{2}$ naik satu satuan maka mempengaruhi komitmen kerja dalam meningkatkan kinerja karyawan sebesar 0,323 .

5. Dari uji korelasi berganda digunakan untuk mengetahui hubungan antara dua variabel independen secara bersama- 
sama atau lebih dengan satu variabel dependen. Koefisien Korelasi disimbolkan dengan huruf R. Besarnya Koefisien Korelasi adalah antara $-1 ; 0$; dan +1. Tingkat hubungan nilai korelasi adalah sebagai berikut :

a. tidak ada korelasi $=0,00 \mathrm{~s} / \mathrm{d}$ 0,20

b. korelasi lemah $=0,21 \mathrm{~s} / \mathrm{d}$ 0,40

c. korelasi sedang $=0,41 \mathrm{~s} / \mathrm{d}$ 0,60

d. korelasi kuat $=0,61 \mathrm{~s} / \mathrm{d} 0,80$

e. korelasi sempurna $=0,81 \mathrm{~s} / \mathrm{d}$ 1,00

Pada penelitian ini dapat diketahui bahwa korelas antara variabel bebas disiplin kerja dan komitmen kerja terhadap variabel terikat kinerja karyawan adalah sebesar $\mathrm{R}=0,742$. Dilihat dari tingkat hubungan korelasi dapat disimpulkan bahwa hubungan antara variabel adalah korelasi kuat.

6. Dari uji koefisien determinasi digunakan untuk mengukur besarnya kontribusi variabel bebas disiplin kerja $\left(\mathrm{X}_{1}\right)$ dan komitmen kerja $\left(\mathrm{X}_{2}\right)$ yang diteliti terhadap variasi variabel terikat $(\mathrm{Y})$ kinerja karyawan .

Pada penelitian ini dapat disimpulkan bahwa pengaruh variabel bebas disiplin kerja dan komitmen kerja terhadap kinerja karyawan memberikan kontribusi sebesar $55,1 \%$ sedangkan sisanya $44,9 \%$ dijelaskan oleh variabel bebas lain atau faktor lain yang tidak dimasukkan ke dalam model persamaan atau penelitian ini.

7. Dari hasil uji t digunakan untuk menguji secara parsial variabel bebas terhadap variabel terikat. Pengujian ini dilakukan dengan membandingkan nilai thitung dengan $t_{\text {tabel }}$. Apabila $t_{\text {hitung }}>t_{\text {tabel }}$ dengan signifikansi $0,05 \quad(5 \%)$, maka secara parsial variabel bebas berpengaruh terhadap variabel terikat. Begitu juga sebaliknya,

Pada penelitian ini dapat diperoleh nilai thitung disiplin kerja sebesar 3,160 > 2,037 ( $\left.\mathrm{t}_{\text {tabel }}\right)$ yang berarti bahwa disiplin kerja mempunyai pengaruh yang signifikan terhadap kinerja karyawan,

sedangkan komitmen kerja memiliki nilai $t_{\text {hitung }}$ sebesar $1,626<2,037 t_{\text {tabel }}$ yang berarti 
bahwa komitmen kerja tidak mempunyai pengaruh yang signifikan terhadap kinerja karyawan.

8. Dari tabel regresi berganda diperoleh $F_{\text {hitung }}$ sebesar 19,635 sedangkan $F_{\text {tabel }}$ sebesar 3.29. karena Fhitung lebih besar daripada $\mathrm{F}_{\text {tabel }}$ maka $\mathrm{H} 0$ ditolak yang artinya bahwa variabel bebas (disiplin kerja dan komitmen kerja) secara bersama - sama mempunyai pengaruh yang signifikan terhadap kinerja karyawan.

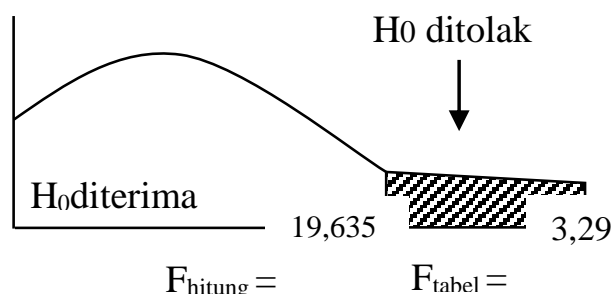

\section{Gambar 1}

\section{Kurva penolakan hasil uji F}

9. Dengan melihat hasil koefisien regresi dari masing - masing variabel bebas yaitu displin kerja $\mathrm{X}_{1}=0,652$ dan komitmen kerja $\mathrm{X}_{2}=0,323$ maka dapat disimpulkan bahwa variabel yang paling dominan mempengaruhi kinerja karyawan adalah variabel disiplin kerja.

\section{KESIMPULAN}

Berdasarkan uraian hasil penelitian dan pembahasan pada Bab $\mathrm{V}$ maka dapat ditarik kesimpulan dari penelitian tentang pengaruh penerapan disiplin kerja dan komitmen kerja tehadap kinerja karyawan pada pabrik pengolahan kedelai di desa laren lamongan. Maka dapat diambil kesimpulan sebagai berikut : Bahwa pengaruh penerapan disiplin kerja $\left(X_{1}\right)$ dan komitmen kerja $\left(\mathrm{X}_{2}\right)$ mempunyai pengaruh secara parsial terhadap kinerja karyawan pada pabrik pengolahan kedelai di desa laren lamongan. Dengan hasil penelitian yang didukung jurnal dan penelitian dari Aris Nur Wahyudi (2016), Olga Riza Roszita (2016), dan M. IqbalAl Awwali (2015) yang sama-sama menyatakan bahwa variabel bebas (X) gaya kepemimpinan, motivasi,disiplin kerja, standar operasional dan komitmen kerja berpengaruh secara parsial terhadap variabel terikat (Y) kinerja karyawan.

Bahwa pengaruh penerapan disiplin kerja $\left(\mathrm{X}_{1}\right)$ dan komitmen kerja $\left(\mathrm{X}_{2}\right)$ memiliki pengaruh secara simultan terhadap kinerja karyawan 
pada pabrik pengolahan kedelai di desa laren lamongan. Hasil penelitian ini didukung jurnal dan penelitian dari Aris Nur Wahyudi (2016), Olga Riza Roszita (2016), dan M. IqbalAl Awwali (2015) yang sama-sama menyatakan bahwa variabel bebas (X) gaya kepemimpinan, motivasi,disiplin kerja, standar operasional dan komitmen kerja berpengaruh secara simultan terhadap variabel terikat $(\mathrm{Y})$ kinerja karyawan.

Diantara pengaruh penerapan disiplin kerja $\left(\mathrm{X}_{1}\right)$ dan komitmen kerja $\left(\mathrm{X}_{2}\right)$ yang memiliki pengaruh paling dominan terhadap kinerja karyawan (Y) pada pabrik pengolahan kedelai didesa laren lamongan adalah disiplin kerja. Hasil penelitian ini menolak jurnal Aris Nur Wahyudi (2016) yang menyatakan bahwa gaya kepemimpinan memiliki pengaruh paling dominan terhadap kinerja karyawan. Namun hasil penelitian M.Iqbal- Al Awwali (2015) dan Olga Riza Roszita (2016) yang samasama menyatakan bahwa disiplin kerja memiliki pengaruh paling dominan terhadap kinerja karyawan.

\section{DAFTAR PUSTAKA}
A.A.Anwar Prabu
Mangkunegara.2013.
Manajemen Sumber Daya Manusia Perusahaan,
Bandung: $\quad$ PT.Remaja
Rosdakarya

Aris Nur Wahyudi, 2016. Dengan Judul Pengaruh Gaya Kepemimpinan, Motivasi Dan Disiplin Kerja Terhadap Kinerja Karyawan PT. Pegadean (Persero) Cabang Lamongan".

Arikunto, S. (2010). Prosedur Penelitian Suatu Pendekatan Praktik. Jakarta: Renika Cipta.

Allen, N.J \& Meyer, J.P. 1990. The Measurement And Antecedents Of Affective Continuance And Normative Commitment To The Organization. Journal Of Occupational Psychology.63, 1-18

Darmawan, D.2013. Prinsip-Prinsip Perilaku Organisasi. Surabaya:Pt. Temprina Media Grafika

Dr. H. Suwanto, M. SI. 2014. Manajemen sumber daya manusia dalam organisasi publik dan bisnis. Bandung: CV. Alfabeta.

Donni Juni Priansa, S.Pd., S.E., M.M. 2014. Manajemen sumber daya manusia dalam organisasi publik dan bisnis. Bandung: CV. Alfabeta.

Hasibun, Melayu S.P 2016. Manajemen Sumber Daya 
Manusia. Edisi Revisi. Jakarta : Penerbit PT. Bumi Aksara.

Indah puji, 2014. Buku Praktis Mengembangkan Sumber Daya Manusia, Yogjakarta.

Kreitner, Robert dan Angelo Kinicki. 2014. Perilaku Organisasi. Edisi 9. Buku 1. Jakarta: Salemba Empat

Lilyana rahmadhani,2016. Dengan judul "Pengaruh Kedisiplinan Dan Gaji Karyawan terhadap Efektifitas Kinerja Karyawan di KPRI Setia Praja Pemkab Lamongan”.

M. Iqbal-Al Awwali, 2015. Dengan judul "pengaruh disiplin kerja dan pendidikan karyawan terhadap prestasi kerja karyawan di PT. Wiharta Karya Agung Gresik”

Moekijat. 2010. Produktifitas Sumber Daya Manusia. Bandung: Mandar Maju.

Mondy, r. R. (2010). Manajemen Sumber Daya Manusia. Jakarta: Erlangga.

Noe, R.A., Hollenback, J.R., Gerhart, B. And Wright,P.M. (2011). Manajemen Sumber Daya Manusia: Mencapai Keunggulan Bersaing. Edisi 6, Jilid 2. Terjemahan David Wijaya, Jakarta: Salemba Empat.

Priansa D.J.2014. Perencanaan dan pengembangan SDM. Bandung: CV. Alfabeta.

Rivai, Veithzal dan ella jaunavi sagala, 2013. Manajemen
Sumber Daya Manusia untk perusahaan, Rajawali pers, Jakarta

Robbins, S.P Dan Timothy A. Judge. 2015. Perilaku Organisasi,Edisi 16. Salemba Empat, Jakarta

Sinambela, Lijan Poltan. 2012. "Kinerja Pegawai Teori Pengukuran Dan Implementasi". Penerbit Graha Ilmu: Yongyakarta.

Sedarmayanti. 2013. Manajemen sumber daya manusia. Refika aditama, Bandung

Sutrisno, Edy. 2013. Manajemen Sumber Daya Manusia. Edisi Pertama, Jakarta : Kencana.

Sugiyono. 2017. Metode penelitian kuantitatif, kualitatif, dan $R \& D$, Bandung: ALFABETA

Tubagus Agil, 2018. "Pengaruh Implementasi Standar Operasional Prosedur kerja terhadap Peningkatan Produktifitas buruh berdasarkan prespektif ekonomi islam pada PT. Indokom Samudra Persada".

Umam, Khaerul. (2012). Perilaku Organisasi. Bandung: CV. PUSTAKA SETIA. 
